\title{
The Use of Gurindam Dua Belas (G12) as a Learning Resource in Islamic Education
}

\author{
Zaitun \\ Department of Character and General Education, \\ Indonesia Univeristy of Education \\ Department of Indonesian Language and Literature \\ Education, Faculty of Education, Maritim Raja Ali \\ Haji University, Tanjungpinang \\ zaitun@student.upi.edu ,zaitun@umrah.ac.id
}

\author{
Kama Abdul Hakam \\ Department of Character and General Education, \\ Indonesia Univeristy of Education \\ kama.hakam@gmail.com
}

\author{
Yadi Ruyadi \\ Department of Character and General Education \\ Indonesia Univeristy of Education \\ yadiruyadi016@upi.edu
}

\begin{abstract}
The research aims at describing how Gurindam Dua Belas (G12) is used as a learning resource in Islamic Education. G12 is a documenttype literary work derived from the local wisdom of Riau Islands' Malay. In Islamic Education classrooms, the use of G12 benefits the students because of its great rhythms, meanings, values, and life lessons. This research employs descriptive methodology with qualitative approach. Based on the primary and secondary source analysis, the conclusion can be drawn that the 12 chapters of Gurindam implicitly embodies life lessons and good character models that are suitable for an Islamic Education class. In detail, G12 can: a) introduce and promote the local wisdom of Riau Islands' Malay, b) nurture the students' religious values and good characters, c) promote the students' motivation and learning experience, and d) stimulate the teachers' creativity. In conclusion, G12 as a learning source can stimulate religious, communicative, and engaging learning experience despite of the challenges it may face in its implementation.
\end{abstract}

Keywords: Islamic Education, Utilization, Gurindam Dua Belas (G12), Learning Source.

\section{INTRODUCTION}

Indonesia has rich and diverse local traditions, reflected in the society's diverse ethnicities, cultures or traditions, local languages, and beliefs. The local traditions are also commonly known as local wisdoms. A literary work from Riau Islands' Malay entitled Gurindam Dua Belas is an example. Efendy describes Gurindam Dua Belas as a monumental work created by public and religious figures from Melayu Kingdom which was famously known from its ideology of good character education in the context of Indonesia and
Malay community[1]. Gurindam Dua Belas by Raja Ali Haji is categorized as a puisi lama (old poetry). Terminologically, Raja Ali Haji in Bustan Al-Katibin described gurindam as a combination of two complementary lines or stanzas with the same rhyme. The first line is called sampiran, and the second one is called jawab or maksud [2]. It has 12 chapters or 86 stanzas. G12 is categorized as a didactic religious literature, also known as Syi'ir Al Irsyad, because its content mostly talks about tasawuf knowledge. G12 highlights good character building, and religious counseling. It is believed that the themes are a potential and smart solution to eliminate the identity and moral degradation in our society.

The interactions in the college context, for example, the moral degradation could clearly be seen on the facts that some students talk less politely to their colleagues, department staff, and their professors, particularly in text messages and phone conversations. Another degradation could also be noticed from their less appropriate attitudes at the university, such as unpunctuality and dishonesty or plagiarism. Regarding the religious practices, based on researchers' observation, some of them no longer perform the prayers punctually (especially Dzuhur and Ashr prayer). In addition, they no longer celebrate Islamic Special days. The two examples showcase that they are less obediant to perform Islamic commands.

Those phenomena are often considered as the solely Islamic Education responsibility to fix. In fact, all lecturers at the university have the same responsibility. AL-Nahlawi stated that: "Islamic Education is a gradual effort in preserving, nurturing, and developing the students' original positive character and potentials in their journey to the merit and perfection that Allah granted" [3]. In a college, Islamic Education is described as an education program aiming at developing Islamic values and constructing integral positive personalities through classroom learning process. Islamic education 
expects the students to fully devote themself to perform the Islamic obligations, not merely experts in Islamic knowledge.

The objectives of Islamic Education System in universities are closely related to the objectives of Islamic Education in general and specific contexts. Azra underlined that education aims to develop human's personality in a comprehensive and proportional manner through people's training on spirit, intellectuality, reasonability, sensibility, physic, language, imagination, and feeling [4]. Those trainings need to be done personally and collectively in order to achieve perfection. The ultimate objective of Muslim education lies in pure devotion to Allah as an individual, a group, and a part of human race. Furthermore, HarunNasution said that Islam Education in school is generally aimed at shaping humans' devotion to Allah in order to achieve good personality (akhlakulkarimah) [5].

Gurindam 12 is a document-type literary work which can be utilized as an alternative learning resource for Islamic Education by teachers. G12 created by a poet always has values and meanings to learn and implement in daily life. Idris stated "Gurindam works as a trigger to personality development of an individual, a community, or a nation. It can be seen from its contents which cover infinite instances of morality" [6]. The values of dignified language in G12 are definitely addressed to all community circles and classes so they can develop good personality. Zaitun stated that the language used in G12 is based on 6 communication principles stated in The Quran; qaulan sadida (accuracy), qaulan ma'rufa (appropriateness), qaulan Baliqha (efficiency), qaulan maysura (understandability), qaulan karima (dignity), and qaulan layyina (lenience). In addition, it also contains the values 1) truth, 2) honesty, 3) justice, 4) virtue, 5) uprightness, 6) lenience, 7) politeness, 8) appropriateness, 9) respect, 10) loyalty, 11) optimism, 12) beauty, 13) joy, 14) logic, 15) fluency, 16) clarity, 17) accuracy, 18) ability to move hearts, 19) harmony, 20) impression, 21) calmness, 22) efficiency, 23) tenderness, 24) generosity, 25) grace, and 26) humbleness[7].

In fact, despite its appropriateness and benefits, a literary work, G12, is uncommon to be practiced in Islamic Education classes. It is also extremely important to choose a proper topic for the classroom material. The above-mentioned phenomena and situations encourage the researchers to conduct research on the use of G12 as a teaching resource in Islamic Education classroom.

\section{METHOD}

This research methodology was qualitative with descriptive approach. The researchers collected related primary and secondary resources and found that G12 consisted of 12 chapters which were mainly about akhlak (character) as a teaching resource in Islamic Education. The sampling process aimed at gathering the utmost data or information from a number of sources. The information was, then, explored in order to find the research basis. The researchers acted as the research instrument. The data were collected using observations, interviews, and document review.

After primary and secondary data collection, the data were analyzed using Peirce's semiotics analysis method, covering:

1. Heuristic and hermeneutic reading, inventorizing, and intensive identification of the themes related to Islamic ideology contained in G12.

2. Interpretation making according to the Peirce's semiotics theory aiming at identifying, analyzing, and interpreting good character and moral values. Peirce categorizes three types of signs: icon, index, and symbol [8].

3. Making conclusion of the interpretation related to the themes, in particular about good character, in G12.

\section{RESULT}

The use of Gurindam Dua Belas as a learning resource has to consider its appropriateness towards the topic discussed in the classroom. In his study, Malik stated that G12 contains good character values such as: religious devotion, kindness, diligence, politeness, honesty, discipline, independence, care, sincerity, wisdom, humbleness, critical thinking skill, adamancy about truthfulness, physical devotion, positive thinking, hard working, and responsibility [9]. Those values should be discussed thoroughly to the students in the learning process. Those values are also consistent with the law No. 20, 2003, which states that "education aims at to form personality that is devoted to Allah SWT, dignified, healthy, knowledgeable, competent, independent, democratic and responsible as a citizen" [10].

Table 1: The present study focuses on personality-related Chapter Good personality themes

Chapter Thou shall not be rebellious to your father, 10 otherwise Allah would be wrathful. Thou shall respect your mother, so you will be safe.

Thou shall not neglect your son/daughter, otherwise they cannot rise to the town house (they cannot be successful)

Thou shall not be unfaithful to your wife, otherwise it will bring disgrace

Thou shall be fair and honest to your friends, so they can give you an employment

\begin{tabular}{|c|c|}
\hline \multirow[t]{5}{*}{$\begin{array}{l}\text { Chapter } \\
11\end{array}$} & $\begin{array}{l}\text { Thou shall help people with the same } \\
\text { nationality }\end{array}$ \\
\hline & Thou shall be a leader and behave properly \\
\hline & $\begin{array}{l}\text { Thou shall seek for evidence before being } \\
\text { angry }\end{array}$ \\
\hline & Thou shall not overtake others' turn \\
\hline & $\begin{array}{l}\text { Thou shall be kind in order to make many } \\
\text { friends }\end{array}$ \\
\hline
\end{tabular}


The present study focuses on personality-related themes in G12. The personality or akhlak is related to the "horizontal" human-to-human interaction, as well as the "vertical" human-to-God devotion. Several themes are extracted from chapter, 3, 4, 7, 8, 10, and 11 of G12. The following Table 1 the themes identified in chapter 10 and 11 of G12.

In the agenda of the utilization of G12 in the classroom, lecturers of Islamic Education are expected to consider the following aspects:

1. Implementation stage which includes; selecting the themes, explaining the implicit meaning, integrating the themes into the learning, using cooperative learning model, and making use of audio-visual media.

2. The benefits that are expected to gain; preserving one of local wisdoms of Riau Islands' Malay community, improving the students motivation, improving the lecturers' creativity, improving the students' (and the lecturers') devotion to Allah SWT, and shaping the students' good character.

3. The challenges which may be faced; the insufficiency of lecturers' competency, the low appreciation towards G12 from the students, and the difficulty in formulating the learning evaluation.

Pradopo underlined "Poetry can play a large role in helping children understand a variety of topics, such us exploring concepts; money, justice, freedom, environment, egocentrism, etc" [12]. Zaitun stated that learning motivations in G12 could also be implemented in the students' life. The motivations can; 1 ) nurture the religious values, 2) build good character, 3) encourage the students to learn more, 4) enrich the lecturer's teaching material, 5) create a good role model (lecturers) in the classroom, and 6) preserve local wisdoms [13]. In fact, the students are able to comprehend the concept better proved by the fact that they are able to explain the concept based on their experience, comprehension, and imagination. Therefore, G12 as learning source might be a completely new innovation in Islamic Education Classrooms.

\section{CONCLUSION}

As one of the general compulsory classes, Islamic Education undeniably plays a strategic and essential role in stimulating, and developing the students' good character when mingling in a society, particularly an interaction and communication in the college. The use of G12 as a learning resource is both creative and essential strategy in the students' character building. The use of G12 is specifically beneficial to; a) introduce local wisdoms of Riau Islands' Malay, b) develope religious values and good character of the students, c) improve the students' motivation, and d) stimulate Islamic Education lecturers' creativity. In conclusion, the utilization of G12 is a stimulant to trigger innovative, religious, interactive, and engaging learning. The ultimate objective is to shape personality forming good character in all aspects of living.

\section{ACKNOWLEDGEMENT}

Praise be to Allah TheAlmighty for all His favors so that this research could be finished, thanks to our beloved family and friends for their prayer and support. On this occasion, the researchers would like to express the appreciation and gratitude to BUDI DN and LPDP as sponsors. The researachers realize this research is far from perfect, but it can benefit all of us who attempt to implement different ways when teaching in islamic education context.

\section{REFERENCES}

[1] Tenas Effendy, Tunjuk Ajar Melayu. Yogyakarta.2006

[2] Raja Ali Haji,Bustan Al Katibin. Kuala Lumpur. 2005

[3] Raja Ali Haji, Gurindam Dua Belasdan Syair Sinar Gemala Mestika Alam. EdisiII. Jogjakarta. 2004

[4] A.Al-Nahlawi, Prinsip-Prinsip dan Metoda Pendidikan Islam dalam Keluarga, di Sekolah dan di Masyarakat (terj. Hery Noer Aly), Bandung.1996

[5] A.Azra, Pendidikan Islam: Tradisi dan Modernisasi Menuju Milenium Baru.Jakarta. 2000.

[6] H. Nasution, Islam Rasional. Bandung.1996

[7] ZubirIdris, Komunikasi Moral Lewat Gurindam Dua Belas Raja Ali Haji ,Jurnal Komunikasi Malaysian Journal of Communication, jilid 31(2). 2015

[8] Zaitun, Telaah Berbahasa Santun dalam Gurindam Dua Belas Raja Ali Haji. Prosiding Seminar Nasional Pendidikan dan Kebudayaan. STKIP Muhammadiyah, Bogor.2017

[9] JhonCresswell, Riset Pendidikan: Perencanaan, Pelaksanaan, dan Evaluasi Riset Kualitatif \& Kuantitatif. Yogyakarta.2015

[10] Abdul Malik, Personal Character Index In The Works Of Raja Ali Haji. International journal of information, technology, business Manajemen. Vol 58. No.1.2017

[11] Depdiknas,Undang-Undang No. 20 Tahun 2003 tentang Sistem Pendidikan Nasional.Jakarta.2003

[12] RahmatDjoko Pradopo, Pengkajian Puisi. Yogyakarta.2010

[13] Zaitun, Manfaat Motivasi Belajar Berbasis Gurindam Dua Belas.2 ${ }^{\text {nd }}$ Internasional Conference on Primary and Early Childhood Education. Bandung. 2017 